\title{
Studies on Antibiotic Production by Soil Microflora and their Biochemical Characterization form Different Industrial Waste Polluted Soil Samples in (Uttar Pradesh \& Uttarakhand) India
}

\author{
Atul Pratap Singh and Sanjay Mishra* \\ School of Biotechnology, IFTM University, Lodhipur Rajput, Delhi Road (NH-24), Moradabad 244 102, U.P., \\ India \\ *Corresponding author: Email: sanjaymishra@iftmuniversity.ac.in
}

\begin{abstract}
Throughout the ages, natural products have been the most consistently successful source of lead compounds that have found many applications in the fields of medicine, pharmacy and agriculture. Microbial natural products have been the source of most of the antibiotics in current use for the treatment of various infectious diseases. Since the discovery of penicillin in 1928, studies on soil bacteria and fungi have shown that microorganisms are a rich source of structurally unique bioactive substances. After Penicillin, many other drugs including chlortetracycline, chloramphenicol, streptomycin, erythromycin, rifamycin, lincomycin, cephalosporin C, vancomycin, erythromycin, nalidixic acid, amphotericin B, nystatin, and daunorubicin the antitumor agent were discovered from microorganisms. Currently, many of the pathogens implicated in infectious disease are rapidly developing resistance to the available antibiotics making treatment of these infections very difficult hence the need to look for more effective antibiotics.
\end{abstract}

Key words: Isolation of antibiotic producers, biochemical characteristics, collection of soil samples, different parameters of antibiotic producers etc.

\section{Background}

Microorganisms have provided a wealth of metabolites with interesting activities such as antimicrobial, antiviral and anticancer. In this study, a total of 50 aquatic microbial isolates from 30 samples (taken from waste polluted soil samples form different industrial areas) were screened by the agar-well diffusion method for ability to produce antibacterial-metabolites. Microorganisms play an essential role in maintaining soil fertility: cycling nutrients, influencing their availability; improving soil structure; supporting healthy plant growth; degrading organic pollutants. Some soil bacteria and fungi cause plant diseases; others are antagonistic to plant pathogens and invertebrate pests. Microorganisms play an essential role in maintaining soil fertility: cycling nutrients, influencing their availability; improving soil structure; supporting healthy plant growth; degrading organic pollutants. Some soil bacteria and fungi cause plant diseases; others are antagonistic to plant pathogens and invertebrate pests. The rhizosphere provides a region of increased microbial activity in which certain groups of bacteria and fungi are more likely to proliferate than in the bulk soil. Some rhizosphere microorganisms originate from the seed but the majority is derived from the soil, in which a plant is growing, and they will be returned to the soil, thus bulk soil and rhizosphere reciprocate impact on microbial communities. This is especially important in the case of plant pathogenic microorganisms and microbial antagonists to pests and pathogens. Any one group of microbes is unlikely to perform with maximum efficiency under all circumstances so genetically diverse populations are needed to provide continuation of important soil processes. Since the relationship between the size, diversity and activity of microbial populations and soil 'quality' is unclear, also how these properties fluctuate throughout the seasons, with crop rotations, and the scale (temporal, spatial) on which they vary, it is difficult to predict effects of changes in agricultural practice, land use, climate, introduction of novel plants, microbial inoculants and pollution on soil quality.

\section{Introduction}

An antibacterial is a compound or substance that kills or slows down the growth of bacteria. The term is often used synonymously with the term antibiotic(s); today, however, with increased knowledge of the causative agents of various infectious diseases, antibiotic(s) has come to denote a broader range of antimicrobial compounds, including antifungal and other compounds.

The term antibiotic was coined by Selman Waksman in 1942 to describe any substance produced by a microorganism that is antagonistic to the growth of other microorganisms in high dilution. This definition excluded substances that kill bacteria, but are not produced by microorganisms (such as gastric juices and hydrogen peroxide). It also excluded synthetic antibacterial compounds such as the sulfonamides. 
Many antibacterial compounds are relatively small molecules with a molecular weight of less than 2000 atomic mass units.

A few decades after the introduction of antibiotics into clinical practice, resistance by pathogenic bacteria has become a major health concern. Indeed, infectious diseases were considered virtually conquered. Many Gram positive bacteria and Gram negative opportunistic pathogens were becoming resistant to virtually every clinically available drug. The use of antimicrobial drugs for prophylactic or therapeutic purposes in human and veterinary or for agricultural purposes, have provided the selective pressure favoring the survival and spread of resistant organisms. Staphylococcus aureus, for instance, a virulent pathogen that is responsible for a wide range of infections including pimples, pneumonia, osteomyelitis, endocarditis and bacteremia, has developed resistance to most classes of antibiotics. Methicillin-resistant S. aureus (MRSA) strains appeared in the hospital environment after introduction of the semi-synthetic penicillin and methicillin, leaving vancomycin as the last chance for MRSA treatment Vancomycin is the last tool for the treatment of the infections caused by the resistant Gram positive microorganisms including MRSA. Indeed, vancomycin resistance is difficult to acquire because it is a complex system involving up to 7 genes. However vancomycin-intermediately-sensitive S. aureus were first isolated in 1997 in Japan and later in other countries. In fact, vancomycin-resistant clinical isolates have been recently reported. Thus currently, no antibiotic class is effective against multi-resistant $S$. aureus infections and new antibiotics or alternative chemotherapeutic strategies are urgently needed.

The activity and diversity of soil organisms are regulated by a hierarchy of abiotic and biotic factors. The main abiotic factors are climate, including temperature and moisture, soil texture and soil structure, salinity and $\mathrm{pH}$. Overall, climate influences the physiology of soil organisms, such that their activity and growth increases at higher temperatures and soil moistures as climate conditions differ across the globe and also, in the same places, between seasons, the climatic conditions to which soil organisms are exposed vary strongly. Soil organisms vary in their optimal temperature and moisture ranges, and this variation is life-stage specific, e.g. larvae may prefer other optima than adults. For instance, for springtails, the optimum average temperature for survival is just above $20^{\circ} \mathrm{C}$, and the higher limit is around $50{ }^{\circ} \mathrm{C}$, while some bacteria can survive up to $100^{\circ} \mathrm{C}$ in resistant forms. Soil texture and structure also strongly influences the activity of soil biota. For example, medium-textured loam and clay soils favor microbial and earthworm activity, whereas fine textured sandy soils, with lower water retention potentials, were less favorable. Soil salinity, which may increase near the soil surface, can also cause severe stress to soil organisms, leading to their rapid desiccation. However, the sensitivity towards salinity differs among species, and increased salinity may sometimes have positive effects, by making more organic matter available. Similarly, changes in soil $\mathrm{pH}$ can affect the metabolism of species (by affecting the activity of certain enzymes) and nutrient availability, and are thereby often lethal.

Until recently, majority of antimicrobial compounds were isolated from terrestrial microorganisms. In the last two decades however, the rate of discovery of novel compounds from this source has significantly declined, as exemplified by the fact that extracts from soil-derived Actinomycetes have yielded high numbers of clinically unacceptable metabolites. The aquatic environment is now becoming increasingly appreciated as a rich and untapped reservoir of useful novel natural products. The marine environment alone is known to contain taxonomically diverse bacterial groups which exhibit unique physiological and structural characteristics that enable them to survive in extreme environmental conditions, with the potential production of novel secondary metabolites not observed in terrestrial microorganisms. Several compounds including pestalone, hypoxysordarin and equisetin, isolated from sea microorganisms have shown promising antibacterial, antifungal and antiviral activities respectively. Salinosporamide A isolated from marine Salinispora tropica, has been shown to exhibit both anticancer and antimalarial activities and is currently undergoing clinical trial to soil organisms. The availability of phosphorus (P), for example, is maximized when soil $\mathrm{pH}$ is neutral or slightly acidic, between 5.5 and 7.5. Soil organisms influence plants and organisms that live entirely aboveground, and these influences take place into two directions. Plants can strongly influence the activity and community composition of microorganisms in the vicinity of their roots (called the rhizosphere). In turn, plant growth may be limited, or promoted by these soil microorganisms. Added to this, plants can influence the composition, abundance and activity of regulators and ecosystem engineers, whereas these species in turn can influence vegetation composition and productivity. Finally, soil organisms can induce plant defence responses to aboveground pests and herbivores and the aboveground interactions can feed back in a variety of ways to the biodiversity, abundance and activities of the soil organisms. In addition, within the soil food webs, each functional group can be controlled by bottom-up or top down biotic interactions. Top-down effects are mainly driven by predation, grazing, and mutualism relationships. Bottom-up effects depend largely on competitive interactions for access to resources.

Many of the functions performed by soil organisms can provide essential services to human society. Most of these services are supporting services, or services that were not directly used by humans but which underlie the provisioning of all other services. These include nutrient cycling, soil formation and primary production. In addition, soil biodiversity influences all the main regulatory services, namely the regulation of 
atmospheric composition and climate, water quantity and quality, pest and disease incidence in agricultural and natural ecosystems, and human diseases. Soil organisms may also control, or reduce environmental pollution. Finally, soil organisms also contribute to provisioning services that directly benefit people, for example the genetic resources of soil microorganisms can be used for developing novel pharmaceuticals. More specifically, the contributions of soil biodiversity can be grouped under the six following categories:

\section{Soil structure, soil organic matter and fertility:}

Soil organisms are affected by but also contribute to modifying soil structure and creating new habitats. Soil organic matter is an important 'building block' for soil structure, contributing to soil aeration, and enabling soils to absorb water and retain nutrients. All three functional groups are involved in the formation and decomposition of soil organic matter, and thus contribute to structuring the soil. For example, some species of fungi produce a protein which plays an important role in soil aggregation due to its sticky nature. The decomposition of soil organic matter by soil organisms releases nutrients in forms usable by plants and other organisms. The residual soil organic matter forms humus, which serves as the main driver of soil quality and fertility. As a result, soil organisms indirectly support the quality and abundance of plant primary production. It should be underlined that soil organic matter as humus can only be produced by the diversity of life that exists in soils - it cannot be man-made. When the soil organic matter recycling and fertility service is impaired, all life on earth is threatened, as all life is either directly or indirectly reliant on plants and their products, including the supply of food, energy, nutrients (e.g. nitrogen produced by the rhizobium bacteria in synergy with the legumes), construction materials and genetic resources. This service is crucial in all sorts of ecosystems, including agriculture and forestry. Plant biomass production also contributes to the water cycle and local climate regulation, through evapo-transpiration.

\section{Soil Based on their Microbiological Properties:}

Most soils are classified on the basis of their chemical and physical properties; little has been done to classify soils according to their physicochemical and microbiological properties. The reason for this is that a soil's chemical and physical properties are more readily defined and measured than their microbiological properties. Improved soil quality is usually characterized by increased infiltration; aeration, aggregation and organic matter content and by decreased bulk density, compaction, erosion and crusting. While these are important indicators of potential soil productivity, we must give more attention to soil biological properties because of their important relationship (though poorly understood) to crop production, plant and animal health, environmental quality, and food safety and quality. Research is needed to identify and quantify reliable and predictable biological/ecological indicators of soil quality. Possible indicators might include total species diversity or genetic diversity of beneficial soil microorganisms as well as insects and animals. The basic concept here is not to classify soils for the study of microorganisms but for farmers to be able to control the soil microflora so that biologically-mediated processes can improve the growth, yield, and quality of crops as well as the fertility, and productivity of soils. The ultimate objective is to reduce the need for chemical fertilizers and pesticides (National Academy of Sciences, 1989; 1993).

\section{Classification of Soils Based on the Functions of Microorganisms:}

Soils can be characterized according to their indigenous microflora which performs putrefactive, fermentative, synthetic and zymogenic reactions and processes. In most soils, these three functions are going on simultaneously with the rate and extent of each determined by the types and numbers of associated microorganisms that are actively involved at any one time. A simple diagram showing a classification of soils based on the activities and functions of their predominant microorganisms is presented in Fig. 2.

\section{Disease-Inducing Soils:}

In this type of soil, plant pathogenic microorganisms such as Fusarium fungi can comprise 5 to 20 percent of the total microflora if fresh organic matter with a high nitrogen content is applied to such a soil, incompletely oxidized products can arise that are malodorous and toxic to growing plants. Such soils tend to cause frequent infestations of disease organisms, and harmful insects. Thus, the application of fresh organic matter to these soils is often harmful to crops. Probably more than 90 percent of the agricultural land devoted to crop production worldwide can be classified as having disease-inducing soil. Such soils generally have poor physical properties, and large amounts of energy are lost as "greenhouse" gases, particularly in the case of rice fields. Plant nutrients are also subject to immobilization into unavailable forms.

\section{Disease-Suppressive Soils:}

The microflora of disease-suppressive soils is usually dominated by antagonistic microorganisms that produce copious amounts of antibiotics. These include fungi of the genera Penicillium, Trichoderma, and 
Aspergillus, and Actinomycetes of the genus Streptomyces. The antibiotics they produce can have biostatic and biocidal effects on soil-borne plant pathogens, including Fusarium which would have an incidence in these soils of less than 5 percent. Crops planted in these soils are rarely affected by diseases or insect pests. Even if fresh organic matter with high nitrogen content is applied, the production of putrescent substances is very low and the soil has a pleasant earthy odor after the organic matter is decomposed. These soils generally have excellent physical properties; for example, they readily, form water-stable aggregates and they are well-aerated, and have a high permeability to both air and water. Crop yields in the disease-suppressive soils are often slightly lower than those in synthetic soils. Highly acceptable crop yields are obtained whenever a soil has a predominance of both disease-suppressive and synthetic microorganisms.

\section{Zymogenic Soils:}

These soils are dominated by a microflora that can perform useful kinds of fermentations, i.e., the breakdown of complex organic molecules into simple organic substances and inorganic materials. The organisms can be either obligate or facultative anaerobes. Such fermentation-producing microorganisms often comprise the microflora of various organic materials, i.e., crop residues, animal manures, green manures and municipal wastes including composts. After these amendments are applied to the soil, their number: and fermentative activities can increase dramatically and overwhelm the indigenous soil micro flora for an indefinite period. While these microorganisms remain predominant, the soil can be classified as a zymogenic soil which is generally characterized by a) pleasant, fermentative odors especially after tillage, b) favorable soil physical properties (e.g., Increased aggregate stability, permeability, aeration and decreased resistance to tillage c) large amounts of inorganic nutrients, amino acids, carbohydrates, vitamins and other bioactive substances which can directly or indirectly enhance the growth, yield and quality of crops, d) low occupancy of Fusarium fungi which is usually less than 5 percent, and e) low production of greenhouse gases (e.g., methane, ammonia, and carbon dioxide) from croplands, even where flooded rice is grown.

\section{Synthetic Soils:}

These soils contain significant populations of microorganisms which are able to fix atmospheric nitrogen and carbon dioxide into complex molecules such as amino acids, proteins and carbohydrates. Such microorganisms include photosynthetic bacteria which perform incomplete photosynthesis anaerobically, certain Phycomycetes (fungi that resemble algae), and both green algae and blue--green algae which function aerobically. All of these are photosynthetic organisms that fix atmospheric nitrogen. If the water content of these soils is stable, their fertility can be largely maintained by regular additions of only small amounts of organic materials. These soils have a low Fusarium occupancy and they are often of the disease-suppressive type. The production of gases from fields where synthetic soils are present is minimal, even for flooded rice.

This is a somewhat simplistic classification of soils based on the functions of their predominant types of microorganisms, and whether they are potentially beneficial or harmful to the growth and yield of crops. While these different types of soils are described here in a rather idealized manner, the fact is that in nature they are not always clearly defined because they often tend to have some of the same characteristics. Nevertheless, research has shown that a disease-inducing soil can be transformed into disease-suppressing, zymogenic and synthetic soils by inoculating the problem soil with mixed cultures of effective microorganisms. Thus it is somewhat obvious that the most desirable agricultural soil for optimum growth, production, protection, and quality of crops would be the composite soil indicated in Fig. 2, i.e., a soil that is highly zymogenic and synthetic, and has an established disease-suppressive capacity. This then is the principle reason for seeking ways and means of controlling the microflora of agricultural soils.

\section{Bacteria and Fungi:}

Soils contain an astounding diversity of microbes. Most of the microbes in soil, however, have not been identified. There are methods that allow rough approximation of bacteria and fungi in soil, and show that fungi tend to be higher in undisturbed soils (e.g. no tillage or with accumulation of surface leaf litter). In general, high bacteria: fungi ratios are indicative of more rapid rates of $\mathrm{N}$ mineralization some specific functional groups of soil microbes have been studied in detail (e.g. biological $\mathrm{N}$ fixation and arbuscular mycorrhizal symbiosis). Rhizosphere research has shown that a great deal of activity and diversity is present in the immediate vicinity of the root, and future research may show that organic farming practices may be able to foster rhizosphere processes that retain soil $\mathrm{N}$.

Biological $\mathrm{N}$ fixation is the conversion of $\mathrm{N}_{2}$ to $\mathrm{NH}_{4}{ }^{+}$, and it occurs both by free-living and rootsymbiotic prokaryotes. The Rhizobium/legume symbiosis is most active under $\mathrm{N}$-limiting soil conditions, because $\mathrm{N}$ uptake from the soil is less costly to the plant than supporting the microbial symbiosis in the roots to reduce atmospheric $\mathrm{N}_{2}$. Plant dependence upon this symbiosis decreases when soil $\mathrm{N}$ availability increases. Legume cover crops thus will fix more $\mathrm{N}$ when grown in a soil with low $\mathrm{NH}_{4}{ }^{+}$and $\mathrm{NO}_{3}^{-}$. For example, if 
legumes are planted after excessive $\mathrm{N}$ inputs to a vegetable crop, rates of $\mathrm{N}$ fixation will be low. Under both high and low temperatures, $\mathrm{N}_{2}$ fixation increasingly declines. Legumes have high requirements for $\mathrm{P}$, and $\mathrm{P}$ acquisition is enhanced by arbuscular mycorrhizae (AM), dense cluster roots, and organic acid secretion to increase the availability and extraction of inorganic $\mathrm{P}$, which in turn, increases $\mathrm{N}$-fixation capacity. Arbuscular mycorrhizae (AM) fungi live within the roots of many crop plants (i.e. endosymbionts), and can be important for $\mathrm{N}$ uptake in organically-farmed soils. The use of fungicides in conventional soil is detrimental to this symbiosis. Under high nutrient conditions, the support of the fungal symbiont is an excessive cost to the plant, because the plant roots are able to satisfy the plant's nutrient requirements. AM colonization generally declines in response to $\mathrm{N}$ fertilizations.

Excessive $\mathrm{N}$ can occur in organic systems after over-addition of manure, soluble $\mathrm{N}$ fertilizer, or N-rich cover crops. Compared to conventional agriculture, $\mathrm{N}$ inputs are more expensive and more difficult to apply in organic agriculture, and this makes over-addition less likely, but there are still seasons (e.g. after spring inputs or after harvest) in which $\mathrm{N}$ losses can be problematic for the following reasons. Losses of $\mathrm{N}$ occur as a result of organic matter mineralization and release of $\mathrm{NH} 4$ and then $\mathrm{NO} 3$ that can be leached to groundwater or leave in surface runoff. This mineralization may not coincide with crop uptake in some environments. For example, there can be considerable mineralization in the fall when soils are still warm and leaching rains occur. Microbial reservoirs can immobilize nitrogen if there is sufficient high quality organic matter present in the system. Organic farms, like all ecosystems, are susceptible to gaseous losses of $\mathrm{N}$ as nitric oxide (NO), nitrous oxide $\left(\mathrm{N}_{2} \mathrm{O}\right)$, and nitrogen gas $\left(\mathrm{N}_{2}\right)$ through microbial $\mathrm{N}$ transformations. The first two compounds are environmentally undesirable, but $\mathrm{N}_{2}$ gas is inert, and loss of $\mathrm{N}_{2}$ is simply wasteful of the $\mathrm{N}$ that could otherwise have been available to crops. In general, it is best to avoid high soil $\mathrm{N}$ concentrations and anaerobic conditions, in order to avoid gaseous $\mathrm{N}$ losses.

Nitric oxide is an air pollutant; it reacts with volatile organic compounds to form ozone $\left(\mathrm{O}_{3}\right)$ in the troposphere, and it is also a precursor for nitric acid deposition via atmospheric transport. Nitrous oxide is a potent greenhouse gas that contributes to stratospheric $\mathrm{O}_{3}$ destruction. Both are to be avoided! One of the best ways to achieve low gaseous losses is to make sure that $\mathrm{NH}_{4}{ }^{+}$and $\mathrm{NO}_{3}{ }^{-}$are in low concentrations in the soil, and that continuous plant cover is present and thereby maintains active $\mathrm{N}$ uptake. The main cause of $\mathrm{N}_{2} \mathrm{O}$ emissions is denitrification under wet or anaerobic conditions in the soil. Denitrification takes place when heterotrophic bacteria under oxygen limitation use $\mathrm{NO}_{3}{ }^{-}$as alternative electron acceptor to produce $\mathrm{N}_{2} \mathrm{O}$ and $\mathrm{N}_{2}$. The $\mathrm{N}_{2}: \mathrm{N}_{2} \mathrm{O}$ ratio increases with decreasing $\mathrm{O}_{2}$ availability, and it often decreases under high $\mathrm{NO}_{3}{ }^{-}$availability. Nitrification (see above) is also conducive to generally small gaseous losses of both $\mathrm{NO}$ and $\mathrm{N}_{2} \mathrm{O}$.

Other losses of $\mathrm{N}$ also occur. The emission of ammonia $\left(\mathrm{NH}_{3}\right)$ gas increases at soil $\mathrm{pH}>8$, and ultimately contributes to $\mathrm{N}$ deposition elsewhere in the landscape. Leaching of $\mathrm{NO}_{3}^{-}$, which contaminates groundwater, occurs at high water contents, especially in coarse-textured soils and shallow soils over fractured bedrock substrata. Runoff carries $\mathrm{N}$ in various forms to surface waters. Leaching and runoff losses can be minimized by always having plants present (e.g. cover crops during the off-season) to take up N, to decrease soil moisture by evapotranspiration, and to restrict the movement of surface and drainage water. Therefore, the present study was undertaken with the objectives: (a) to isolate and indentify the source of antibiotic producing microorganisms form different industrial areas; (b) to study soil samples site near by the different industrial areas releases the waste matter in the soil; (c) $\square \quad$ biochemical characterizations of antibiotic producing microorganisms (bacteria and fungi) form different industrial waste soil samples.

\section{Material \& Methods}

\section{Persistence of Antibiotics in Soil:}

There were very few studies on reaction of antibiotics in soil. Photolysis, hydrolysis, biodegradation and binding on to soil particles through adsorption process were some of the reactions of these antibiotics and their products that can take place and influence their persistence in soil. They may form complexes with soluble organic materials and become more mobile and contaminate even groundwater while still in its parent form. Antibiotics like ciprofloxacin, ofloxacin, and virginiamycin degrade very slowly and may persist in soil in its original form up to 15-35 days while bambermycin, tylosin, and erythromycin completely degrade in a period of one month at temperatures ranging from $20-300^{\mathrm{C}}$. Persistence of an antibiotic in the terrestrial environment is the key factor determining its environmental impact. Most of the antibiotic residues in manure generally remain stable during manure storage until its application to agriculture fields. So far, there have been very few studies on the impact of the antibiotics added to the soil through manure, sludge and waste waters on the environment and perhaps none in this country. We need to collect precise data on antibiotic use in animal farming, aquaculture and agriculture and the potential reservoir for residual antibiotics in the terrestrial environment in the country. Besides, research work is needed to understand kinetics of biodegradation and potencies of 
degraded products of various antibiotics in different soils, manures and waste water. This would help us to better understand the eco-toxicological impacts of various antibiotic residues in the environment.

\section{Texture of soil:}

Soil type, whether loam, silt loam or sandy loam matters in the persistence of antibiotics in soil. For example, it has been found that ciprofloxacin was mineralized to $\mathrm{CO}_{2}$ less than $1 \%$ in all the three soils in 25 days of incubation. Strong binding of this antibiotic was sited as the reason for its slow degradation. Half-life of ceftiofur was more than 20 days in sand and only 35 days in clay loam. Half-life of oxytetracycline in marine sediments at a depth of 5 to $7 \mathrm{~cm}$ was more than 300 days as compared to 45 to 50 days for virginiamycin in sandy soil. This shows that antibiotic persistence in soil is determined by not only the soil type but also soil depth. Antibiotics can persist for longer periods if they are lodged in sub-surface soil layers and deep in waters away from sunlight and aeration.

\section{Temperature of soil:}

Most of the degradation process of antibiotics in soil is mediated by soil micro-organisms. Therefore persistence of these compounds in the soil is affected by all those factors that affect the activity of microbes. Soil temperature is an important factor in this respect. As the temperature decreases from the normal range of $25-300 \mathrm{C}$, persistence of antibiotics increases. At 300C, $44 \%$ of chlortetracycline and $23 \%$ of bacitracin remained in the soil after 30days of their application. However, when temperature decreased to $200 \mathrm{C}, 88 \%$ of chlortetracycline, $33 \%$ of bacitracin, $25 \%$ of erythrocin remained in soil. At $40 \mathrm{C}$, almost all chlortetracycline, erythrocin and bambermycin persisted in soil.

\section{Antibiotic Sensitivity:}

Antibiotic sensitivity is a term used to describe the susceptibility of bacteria to antibiotics. Antibiotic susceptibility testing (AST) is usually carried out to determine which antibiotic will be most successful in treating a bacterial infection in vivo. Testing for antibiotic sensitivity is often done by the Kirby-Bauer method. Small wafers containing antibiotics are placed on to a plate upon which bacteria are growing. If the bacteria are sensitive to the antibiotic, a clear ring, or zone of inhibition, is seen around the wafer indicating poor growth. Other methods to test antimicrobial susceptibility include the Stokes method, E-test (also based on antibiotic diffusion) Agar and Broth dilution methods for Minimum Inhibitory Concentration determination.

Ideal antibiotic therapy is based on determination of the etiological agent and its relevant antibiotic sensitivity. Empiric treatment is often started before laboratory microbiological reports are available when treatment should not be delayed due to the seriousness of the disease. The effectiveness of individual antibiotics varies with the location of the infection, the ability of the antibiotic to reach the site of infection, and the ability of the bacteria to resist or inactivate the antibiotic. Some antibiotics actually kill the bacteria (bactericidal), whereas others merely prevent the bacteria from multiplying (bacteriostatic) so that the host's immune system can overcome them. Muller Hinton agar is most frequently used in this antibiotic susceptibility test.

\section{Antibiotic Resistance:}

Antibiotic resistance is a type of drug resistance where a microorganism is able to survive exposure to an antibiotic. Genes can be transferred between bacteria in a horizontal fashion by conjugation, transduction, or transformation. Thus a gene for antibiotic resistance which had evolved via natural selection may be shared. Evolutionary stress such as exposure to antibiotics then selects for the antibiotic resistant trait. Many antibiotic resistance genes reside on plasmids, facilitating their transfer. If a bacterium carries several resistance genes, it is called multiresistant or, informally, a superbug or super bacterium.

The primary cause of antibiotic resistance is genetic mutation in bacteria. The prevalence of antibiotic resistant bacteria is a result of antibiotic use both within medicine and veterinary medicine. The greater the duration of exposure the greater the risk of the development of resistance irrespective of the severity of the need for antibiotics. As resistance towards antibiotics becomes more common a greater need for alternative treatments arises. However, despite a push for new antibiotic therapies there has been a continued decline in the number of newly approved drugs. Antibiotic resistance therefore poses a significant problem.

\section{Test microorganisms for the study:}

\section{Results \& Conclusion}

The Streptomyces flora of 15 soil samples, collected from different locations in the Uttar Pradesh \& Uttarakhand Industrial areas region, were screened for their potential as a source of antibiotics active against antibiotic resistant bacteria. All of the isolates were tested for their ability to produce inhibitory substances against seven test microorganisms (Data not shown). The test microorganisms included 3 Gram positive bacteria, 3 Gram negative bacteria and 1 yeast. Of them S. aureus and S. maltophilia are resistant to the widely used antibiotics. The isolates which exhibited antimicrobial activity against of the test. 10 bacteria, including 
three Gram positive organisms were selected for this study. The morphological examination of these isolates, which were active on the test organisms, indicates that these belong to the Streptomyces genus.

Table No. 1:

\begin{tabular}{|c|c|}
\hline Ingredients & Grams/Litre \\
\hline Soluble Starch & 10.0 \\
\hline Casein & 0.30 \\
\hline Potassium nitrate $\left(\mathrm{KNO}_{3}\right)$ & 2.00 \\
\hline Di-potassium hydrogen orthophosphate $\left(\mathrm{K}_{2} \mathrm{HPO}_{4}\right)$ & 2.00 \\
\hline Magnesium sulphate $\left(\mathrm{MgSO}_{4} .7 \mathrm{H}_{2} \mathrm{O}\right.$ & 0.05 \\
\hline Calcium carbonate $\left(\mathrm{CaCO}_{3}\right)$ & 0.02 \\
\hline Ferrous sulphate $\left(\mathrm{FeSO} \mathrm{SO}_{4} .7 \mathrm{H}_{2} \mathrm{O}\right)$ & 0.01 \\
\hline Agar-agar & 20.0 \\
\hline Final pH: $\mathbf{7 . 2}$ & \\
\hline
\end{tabular}

Table. 2: Antimicrobial susceptibility pattern of the selected target Gram-negative bacterial isolates from waste soil.

\begin{tabular}{|c|c|c|c|c|c|c|c|c|c|}
\hline Isolate name & AMP & AUG & FOX & $\begin{array}{c}\text { Cefuroxi } \\
\text { me }\end{array}$ & $\begin{array}{c}\text { Cefataxi } \\
\text { ne }\end{array}$ & CAZ & AK & GM & Tienam \\
\hline E.coli & $\mathrm{R}$ & $\mathrm{R}$ & $\mathrm{R}$ & $\mathrm{R}$ & $\mathrm{R}$ & $\mathrm{R}$ & $\mathrm{R}$ & $\mathrm{R}$ & $\mathrm{S}$ \\
\hline $\begin{array}{c}\text { Kledsiella } \\
\text { spp. }\end{array}$ & $\mathrm{R}$ & $\mathrm{R}$ & $\mathrm{S}$ & $\mathrm{S}$ & $\mathrm{S}$ & $\mathrm{S}$ & $\mathrm{S}$ & $\mathrm{R}$ & $\mathrm{S}$ \\
\hline $\begin{array}{c}\text { Pseudomona } \\
\text { s spp. }\end{array}$ & $\mathrm{R}$ & $\mathrm{R}$ & $\mathrm{S}$ & $\mathrm{R}$ & $\mathrm{R}$ & $\mathrm{S}$ & $\mathrm{R}$ & $\mathrm{S}$ & $\mathrm{S}$ \\
\hline $\begin{array}{c}\text { Proteus spp. } \\
\text { Citrobacter } \\
\text { spp. }\end{array}$ & $\mathrm{R}$ & $\mathrm{S}$ & $\mathrm{R}$ & $\mathrm{R}$ & $\mathrm{S}$ & $\mathrm{R}$ & $\mathrm{S}$ & $\mathrm{S}$ & $\mathrm{S}$ \\
\hline $\begin{array}{c}\text { Actinobacter } \\
\text { spp. }\end{array}$ & $\mathrm{S}$ & $\mathrm{S}$ & $\mathrm{S}$ & $\mathrm{R}$ & $\mathrm{R}$ & $\mathrm{S}$ & $\mathrm{S}$ & $\mathrm{R}$ & $\mathrm{S}$ \\
\hline
\end{tabular}

$A M P=$ Ampicillin, $A U G=$ Augmentin, $F O X=$ Cefoxitin, $C A Z=$ Ceftazidime, $A K=$ Amikacin, GM= gentamycin

Table. No 3: Antimicrobial activities fungal isolates from different soil sample from industrial waste soil.

\begin{tabular}{|c|c|c|c|c|c|c|c|c|}
\hline \multirow{2}{*}{$\begin{array}{l}\text { Fungal } \\
\text { isolates }\end{array}$} & \multicolumn{8}{|c|}{ Target organisms } \\
\hline & $\begin{array}{c}\text { Klibsiella } \\
\text { spp. }\end{array}$ & $\begin{array}{c}\text { Psudomonas } \\
\text { spp }\end{array}$ & $\begin{array}{c}\text { Proteus } \\
\text { spp }\end{array}$ & E.coli & $\begin{array}{c}\text { Citrobacter } \\
\text { spp }\end{array}$ & $\begin{array}{c}\text { Actinobact } \\
\text { er spp }\end{array}$ & $M R S A$ & CONS \\
\hline F1S1 & & & + & & & + & & + \\
\hline F2S2 & & & & + & + & & & \\
\hline F2S3 & & & + & + & + & + & & + \\
\hline F3S3 & & & & + & + & + & & \\
\hline F4S4 & & & & - & + & _. & $=$ & $=$ \\
\hline F5S5 & & & & + & + & - & $=$ & \\
\hline F6S6 & & & & _ & _ & - & $=$ & \\
\hline F7S7 & & & & & 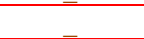 & + & $=$ & \\
\hline F8S8 & & & & & & + & & \\
\hline F9S9 & & & & & & & & \\
\hline F10S10 & & & & 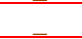 & + & 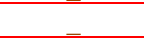 & $=$ & \\
\hline F11S11 & & & 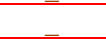 & - & + & - & - & $=$ \\
\hline F12S12 & & & & & & & + & \\
\hline F13S13 & & & & & & & + & \\
\hline F14S14 & & & & & + & & & \\
\hline F1S15 & & & & & & & & \\
\hline F16S16 & & & & & & + & & \\
\hline
\end{tabular}

$F=$ fungal \& $S=$ soil

Table. No 4: Cultural characteristics of the most active antimicrobial agent producing actinomycete strain.

\begin{tabular}{|c|c|c|c|c|}
\hline \multicolumn{1}{|c|}{ Medium } & Growth & Aerial mycelium & Substrate mycelium & Diffusible pigments \\
\hline $\begin{array}{l}\text { 1-Tryptone yeast } \\
\text { extract broth (ISP-1) }\end{array}$ & - & - & - & - \\
\hline $\begin{array}{l}\text { 2-Yeast extract malt } \\
\text { extract agar (ISP-2) }\end{array}$ & Good & $\begin{array}{c}\mathbf{1 6 5 - 1} \text { gray } \\
\text { Medium gray }\end{array}$ & $\begin{array}{c}\text { L6-1-br yellowish Brown } \\
\text { yellowish brown }\end{array}$ \\
\hline
\end{tabular}




\begin{tabular}{|c|c|c|c|c|}
\hline $\begin{array}{l}\text { 3-Oat-meal agar (ISP- } \\
\text { 3) }\end{array}$ & - & - & - & - \\
\hline $\begin{array}{l}\text { 4-Inorganic salts starch } \\
\text { agar medium (ISP-4) }\end{array}$ & Moderate & $\begin{array}{c}\text { 8-gy Grayish } \\
\text { pink }\end{array}$ & $\begin{array}{c}\text { 53-p.OY } \\
\text { Pall orange yellow }\end{array}$ & $\begin{array}{c}\text { 67-brill.Brill. Orange } \\
\text { yellow }\end{array}$ \\
\hline $\begin{array}{l}\text { 5-Glycerol - } \\
\text { asparagine agar (ISP-5) }\end{array}$ & - & $\begin{array}{l}\text { 145-1 Gray } \\
\text { medium gray }\end{array}$ & - & - \\
\hline $\begin{array}{l}\text { 6-Peptone yeast extract } \\
\text { iron agar (ISP-6) }\end{array}$ & Good & 123 Gray light color & $\begin{array}{c}56-1-y-b r \\
\text { Light yellowish Brown }\end{array}$ & $\begin{array}{l}\text { 58-m.Br Moderate } \\
\text { brown }\end{array}$ \\
\hline $\begin{array}{l}\text { 7-Tyrosine agar (ISP- } \\
\text { 7) }\end{array}$ & Good & $25 g y$ pink color & 57-I. Br Light brown & $\begin{array}{c}\mathbf{7 7 -} \text {-m.ybr } \\
\text { moderate yellowish } \\
\text { brown }\end{array}$ \\
\hline
\end{tabular}

Table No.5: Morphology and biochemical characterization of the bacterial isolates

\begin{tabular}{|c|c|c|c|c|c|}
\hline $\begin{array}{c}\text { Key: + } \\
\text { (Positive); }- \\
\text { (negative) }\end{array}$ & BAC 1 & BAC 2 & BAC 3 & BAC 4 & BAC 5 \\
\hline Gram reaction & + & + & & + & + \\
\hline Shape & Bacilli & Cocci & Bacilli & Bacilli & Bacilli \\
\hline Arrangement & Chain & Chain & Chain & Chain & Chain \\
\hline Endospore test & + & _- & + & + & + \\
\hline Motility & + & & & + & + \\
\hline $\begin{array}{l}\text { Oxygen } \\
\text { relationship }\end{array}$ & $\begin{array}{l}\text { Facultative } \\
\text { anaerobe }\end{array}$ & $\begin{array}{c}\text { Facultative } \\
\text { anaerobe }\end{array}$ & Facultative anaerobe & $\begin{array}{l}\text { Facultative } \\
\text { anaerobe }\end{array}$ & $\begin{array}{c}\text { Facultative } \\
\text { anaerobe }\end{array}$ \\
\hline Catalase & + & + & + & + & + \\
\hline \multicolumn{6}{|l|}{ Coagulase } \\
\hline $\begin{array}{l}\text { Citrate } \\
\text { utilization }\end{array}$ & - & + & + & + & - \\
\hline \multicolumn{6}{|l|}{ Indole test } \\
\hline Methyl red & $\overline{+}$ & + & - & - & - \\
\hline $\begin{array}{l}\text { Starch } \\
\text { hydrolysis }\end{array}$ & + & - & + & - & - \\
\hline Glucose & + & & + & + & + \\
\hline Lactose & & & + & & \\
\hline Sucrose & $\overline{+}$ & $\overline{+}$ & + & + & $\overline{+}$ \\
\hline \multicolumn{6}{|l|}{ Mannitol } \\
\hline $\begin{array}{l}\text { Probable } \\
\text { indentify }\end{array}$ & Bacillus lentus & $\begin{array}{c}\text { Micrococcus } \\
\text { roseus }\end{array}$ & $\begin{array}{c}\text { Pseudomonas } \\
\text { auregenosa }\end{array}$ & $\begin{array}{l}\text { Bacillus } \\
\text { pumillus }\end{array}$ & Bacillus alvei \\
\hline
\end{tabular}

Table No. 6: Culture media for most probable number (MPN) analyses

\begin{tabular}{|c|c|c|c|}
\hline Medium & Uses & Incubation temperature & Remark \\
\hline \multicolumn{4}{|c|}{ Isolation media } \\
\hline Lactose broth & Total coliforms & $\begin{array}{l}38 \text { hours at } 35 \pm 0.5^{\circ} \mathrm{C} \text { or } 37 \\
\pm 0.5^{\circ} \mathrm{C} \text { for total coliforms } \\
\text { and } 24 \text { hours at } 44 \pm 0.25^{\circ} \mathrm{C} \\
\text { or } 44.5 \pm 0.25^{\circ} \mathrm{C} \text { for } \\
\text { thermotolerant coliforms }\end{array}$ & $\begin{array}{c}\text { Prepare single strength } \\
\text { medium } \\
\text { by diluting double strength } \\
\text { medium with distilled water. } \\
\text { Each tube or bottle should } \\
\text { contain an inverted } \\
\text { fermentation } \\
\text { (Durham) tube }\end{array}$ \\
\hline $\begin{array}{l}\text { MacConkey } \\
\text { broth }\end{array}$ & $\begin{array}{l}\text { Total or } \\
\text { thermotolerant } \\
\text { coliforms }\end{array}$ & $\begin{array}{l}38 \text { hours at } 35 \pm 0.5^{\circ} \mathrm{C} \text { or } 37 \\
\pm 0.5^{\circ} \mathrm{C} \text { for total coliforms } \\
\text { and } 24 \text { hours at } 44 \pm 0.25^{\circ} \mathrm{C} \\
\text { or } 44.5 \pm 0.25^{\circ} \mathrm{C} \text { for } \\
\text { thermotolerant coliforms }\end{array}$ & \\
\hline $\begin{array}{l}\text { Improved } \\
\text { formate lactose } \\
\text { glutamate } \\
\text { medium }\end{array}$ & $\begin{array}{l}\text { Total or } \\
\text { thermotolerant } \\
\text { coliforms }\end{array}$ & $\begin{array}{l}38 \text { hours at } 35 \pm 0.5^{\circ} \mathrm{C} \text { or } 37 \\
\pm 0.5^{\circ} \mathrm{C} \text { for total coliforms } \\
\text { and } 24 \text { hours at } 44 \pm 0.25^{\circ} \mathrm{C} \\
\text { or } 44.5 \pm 0.25^{\circ} \mathrm{C} \text { for } \\
\text { thermotolerant coliforms }\end{array}$ & $\begin{array}{l}\text { Available commercially in } \\
\text { dehydrated form as Minerals } \\
\text { Modified Glutamate Medium }\end{array}$ \\
\hline $\begin{array}{l}\text { Lauryl tryptose } \\
\text { (lactose) broth }\end{array}$ & $\begin{array}{c}\text { Total or } \\
\text { thermotolerant } \\
\text { coliforms }\end{array}$ & $\begin{array}{l}38 \text { hours at } 35 \pm 0.5^{\circ} \mathrm{C} \text { or } 37 \\
\pm 0.5{ }^{\circ} \mathrm{C} \text { for total coliforms } \\
\text { and } 24 \text { hours at } 44 \pm 0.25^{\circ} \mathrm{C}\end{array}$ & \\
\hline
\end{tabular}




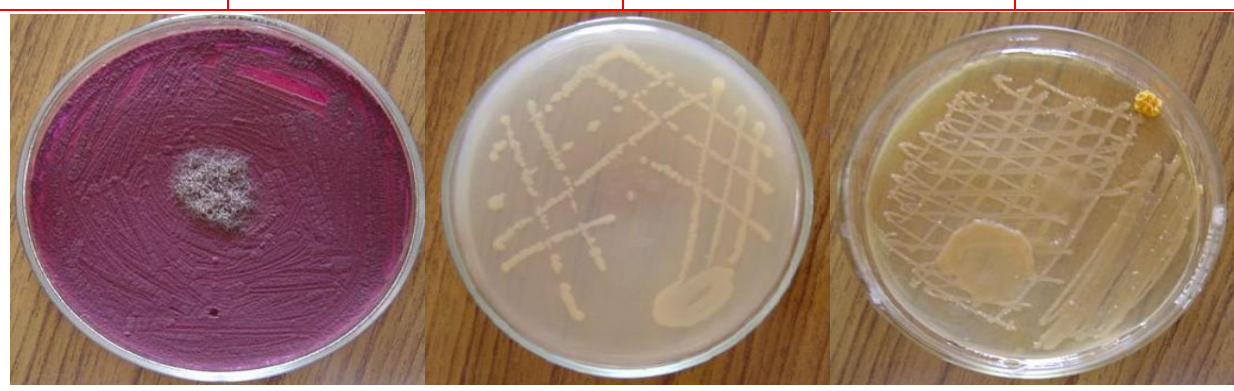

Fig. A: Isolation of Bacillus from industrial waste soil sample.

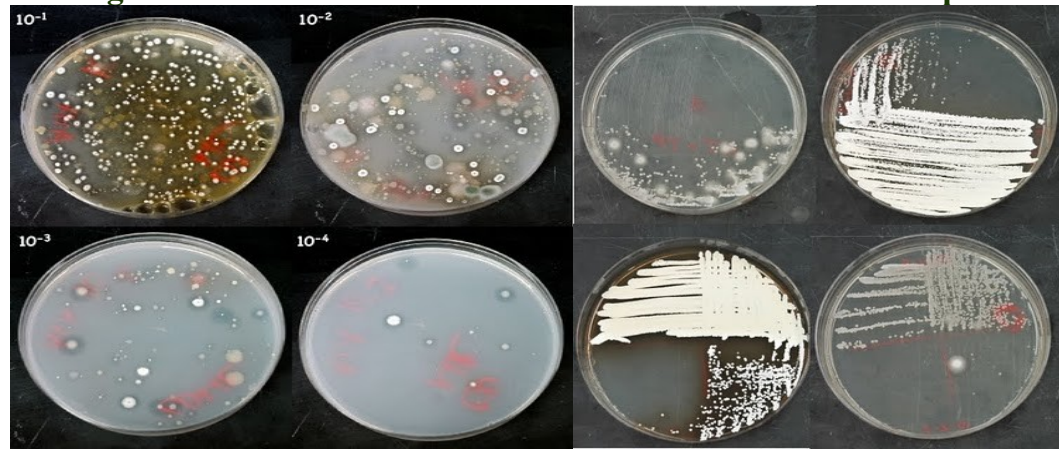

Fig. B: AIA after incubation Figure 6: Streaks for isolated colonies on penassay agar

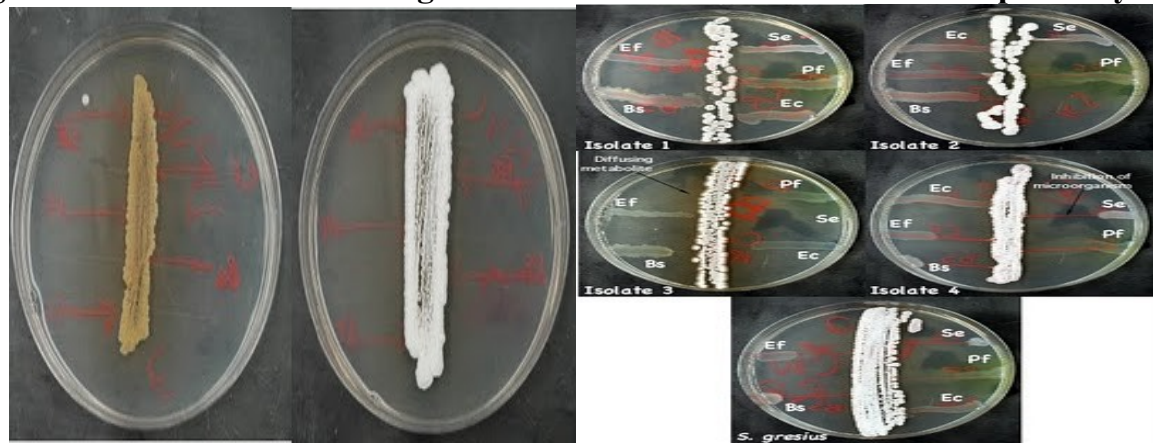

Fig. C: Antimicrobial production by isolates

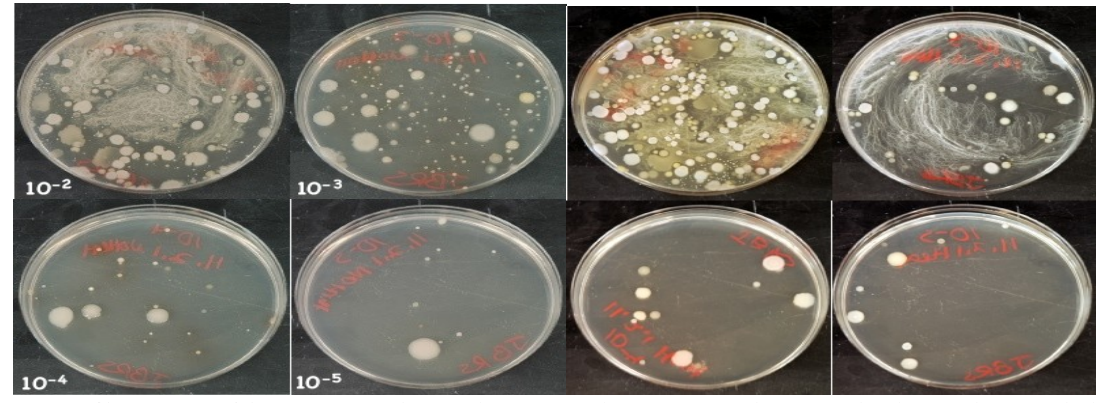

Fig. D: Growth of isolated microbial colonies producing antimicrobial activity.

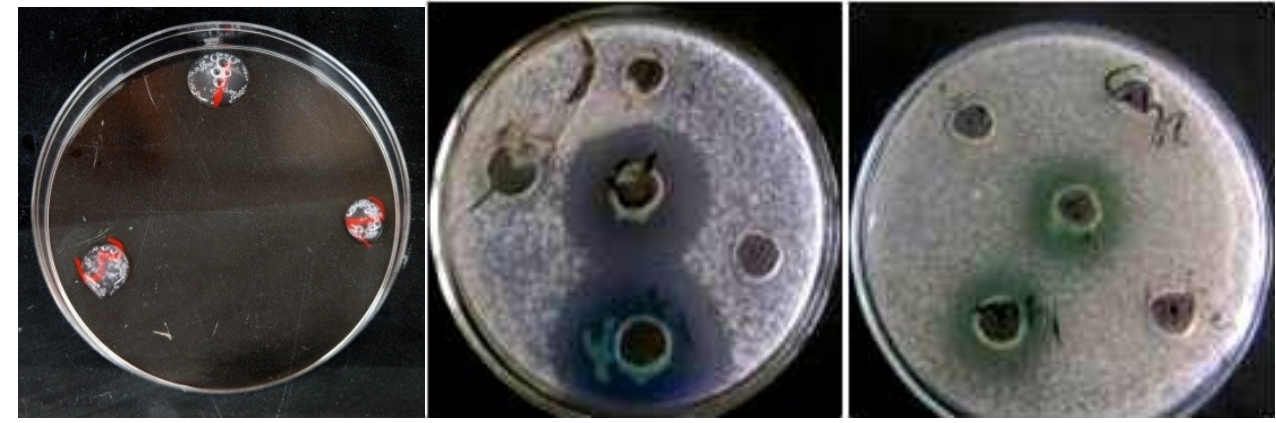

Fig. E: Antibiotic suitability testing against pathogens. 


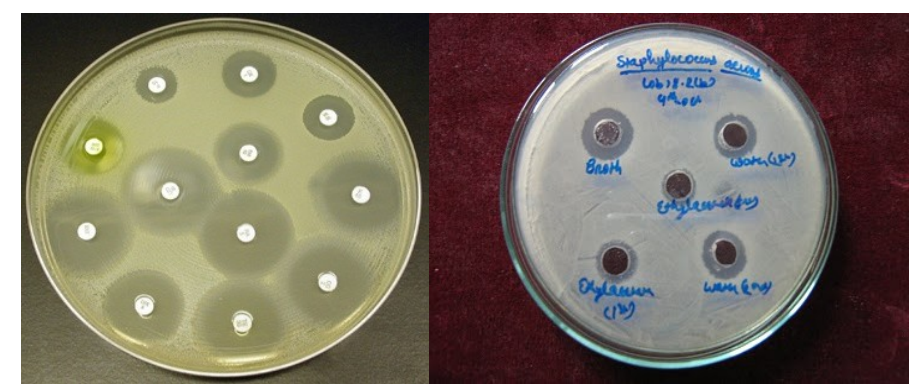

Fig. F: Catalase test for Bacillus isolates
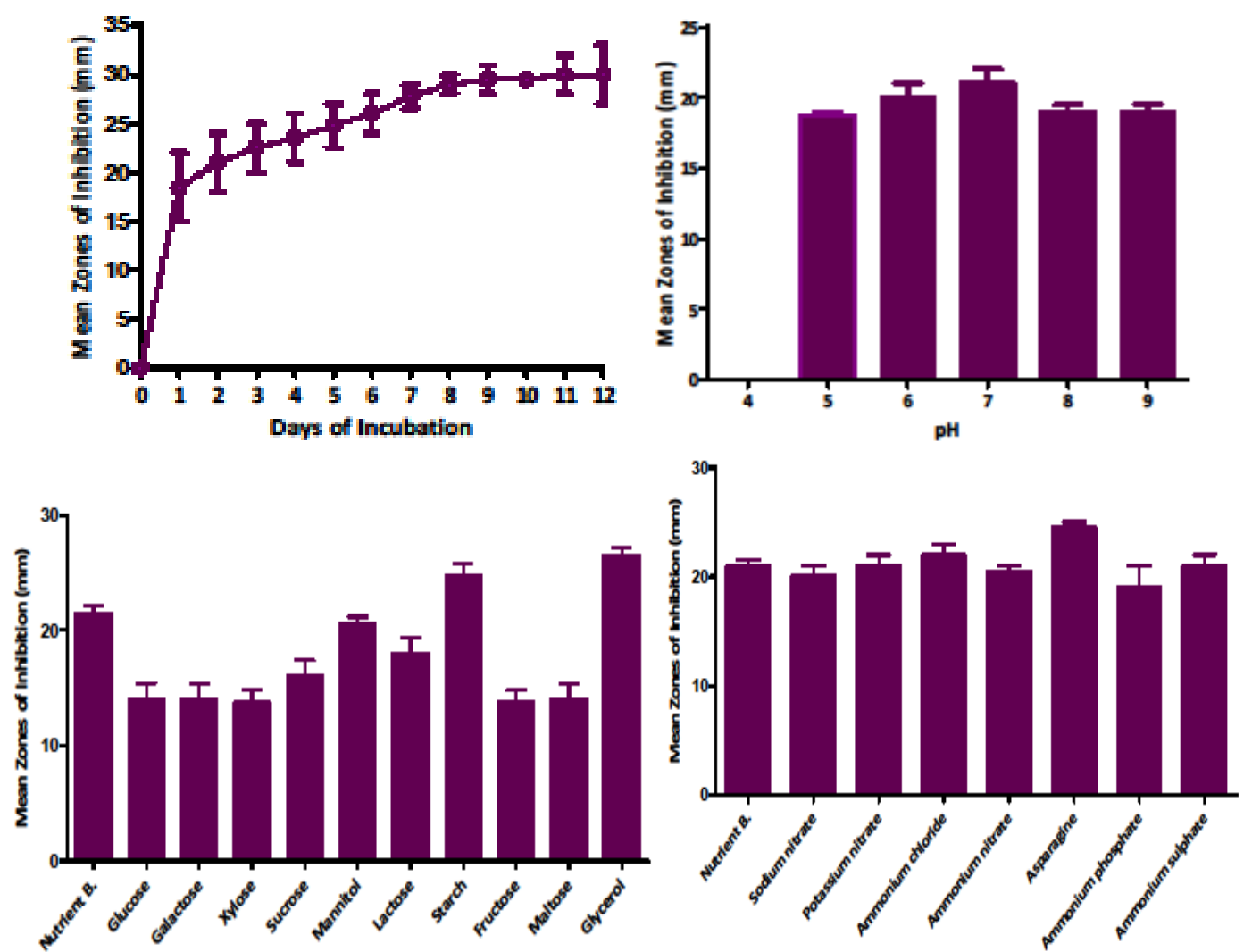

Fig. G: Graphs showing the growth, pH and incubation period of isolated microorganisms from soil.

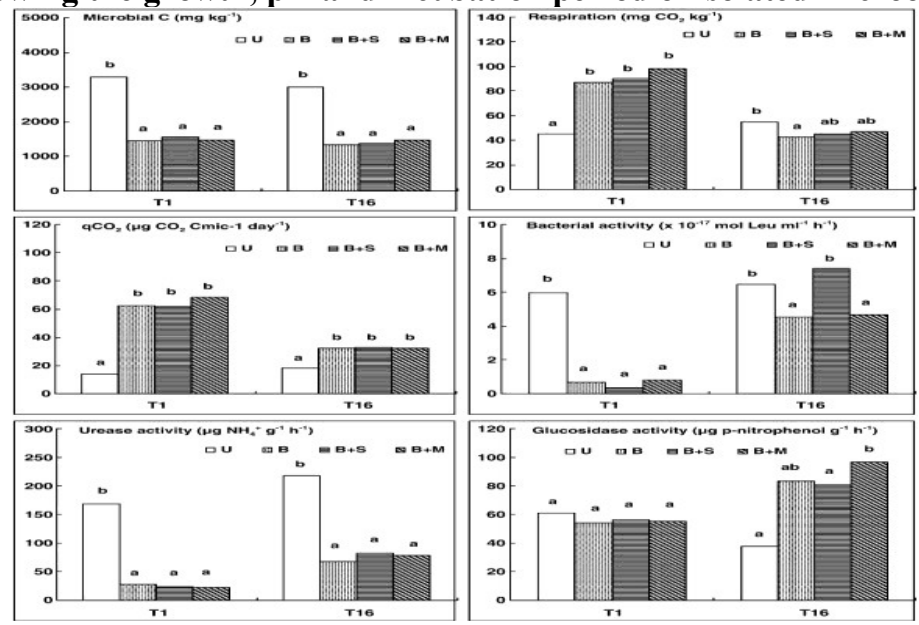

Fig. H: Graphs showing growth of antibiotic producing microorganisms (Bacteria \& Fungi) from waste soil sample. 


\section{Conclusion}

It is concluded that Bacillus lentus, Micrococcus roseus, Enterobacter. Aerogene, Bacillus pumillus and Bacillus alvei isolated during the course of this research from soil samples in different industrial areas have potential of produce antibiotics.

\section{References}

[1] APHA 1992 Standard Methods for the Examination of Water and Wastewater. 18th edition, American Public Health Association (APHA), American Water Works Association (AWWA) and Water Pollution Control Federation (WPCF), Washington, D.C.

[2] Atta et al., 2010aH.M. Atta, S.M. Dabour, S.G. Desoukey Sparsomycin antibiotic production by Streptomyces Sp. AZ-NIOFD1: taxonomy, fermentation, purification and biological activities Am.-Eur. J. Agric. Environ. Sci., 5 (3) (2011), pp. 368-377.

[3] Atta, 2010 H.M. Atta Production, purification, physico-chemical characteristics and biological activities of antifungal antibiotic produced by Streptomyces antibioticus, AZ-Z710 Am.-Eur. J. Sci. Res., 5 (1) (2010), pp. 39-49

[4] Acea, M. J., C. R. Moore, and M. Alexander. 2011. Survival and Growth of Bacteria Introduced into Soil. Soil Biology \& Biochemistry 20:509-515.

[5] Alali, F. Q., T. El-Elimat, C. Li, A. Qandil, A. Alkofahi, K. Tawaha, J. P. Burgess, Y. Nakanishi, D. J. Kroll, H. A. Navarro, J. O. Falkinham, M. C. Wani, and N. H. Oberlies. 2011. New colchicinoids from a native Jordanian meadow saffron, Colchicum brachyphyllum: Isolation of the first naturally occurring dextrorotatory colchicinoid. Journal of Natural Products 68:173-178.

[6] Alali, F. Q., A. Gharaibeh, A. Ghawanmeh, K. Tawaha, and N. H. Oberlies. 2010. Colchicinoids from Colchicum crocifolium Boiss.: A case study in dereplication strategies for Colchicine and related analogs using LC-MS and LC-PDA techniques. Planta Medica 74:1114-1114.

[7] Alali, F. Q., A. S. Ma'aya'h, A. Alkofahi, A. Qandil, C. Li, J. Burgess, M. C. Wani, and N. H. Oberlies. 2010. A new colchicinoid from Colchicum tauri, an unexplored meadow saffron native to Jordan. Natural Product Communications 1:95-99.

[8] Alali, F. Q., K. Tawaha, T. El-Elimat, R. Qasaymeh, C. Li, J. Burgess, Y. Nakanishi, D. J. Kroll, M. C. Wani, and N. H. Oberlies. 2009. Phytochemical studies and cytotoxicity evaluations of Colchicum tunicatum Feinbr and Colchicum hierosolymitanum Feinbr (Colchicaceae): two native Jordanian meadow saffrons. Natural Product Research 20:558-566.

[9] Balser, T. C., J. W. Kirchner, and M. K. Firestone. 2010. Methodological variability in microbial community level physiological profiles. Soil Science Society of America Journal 66:519-523.

[10] Barea, J. M., M. J. Pozo, R. Azcon, and C. Azcon-Aguilar. 2008. Microbial co-operation in the rhizosphere. Journal of Experimental Botany 56:1761-1778.

[11] Begunova, E. A., O. A. Stepnaya, I. M. Tsfasman, and I. S. Kulaev. 2010. The effect of the extracellular bacteriolytic enzymes of Lysobacter sp on gram-negative bacteria. Microbiology 73:267-270.

[12] Cain, C. C., A. T. Henry, R. H. Waldo, L. J. Casida, and J. O. Falkinham. 2009. Identification and characteristics of a novel Burkholderia strain with broad-spectrum antimicrobial activity. Applied and Environmental Microbiology 66:4139-4141.

[13] Cain, C. C., D. H. Lee, R. H. Waldo, A. T. Henry, E. J. Casida, M. C. Wani, M. E. Wall, N. H. Oberlies, and J. O. Falkinham. 2008. Synergistic antimicrobial activity of metabolites produced by a nonobligate bacterial predator. Antimicrobial Agents and Chemotherapy 47:2113-2117.

[14] Casey, J. T., P. K. Walsh, and D. G. O'Shea. 2007. Characterisation of adsorbent resins for the recovery of geldanamycin from fermentation broth. Separation and Purification Technology 53:281-288.

[15] Casida, L. E. 2009. Bacterial Predators of Micrococcus-Luteus in Soil. Applied and Environmental Microbiology 39:1035-1041.

[16] Classen, A. T., S. I. Boyle, K. E. Haskins, S. T. Overby, and S. C. Hart. 2003. Community-level physiological profiles of bacteria and fungi: plate type and incubation temperature influences on contrasting soils. Fems Microbiology Ecology 44:319-328.

[17] Coenye, T., E. Mahenthiralingam, D. Henry, J. J. LiPuma, S. Laevens, M. Gillis, D. P. Speert, and P. Vandamme. 2010. Burkholderia ambifaria sp nov., a novel member of the Burkholderia cepacia complex including biocontrol and cystic fibrosisrelated isolates. International Journal of Systematic and Evolutionary Microbiology 51:1481-1490.

[18] Compeau, G., B. J. Alachi, E. Platsouka, and S. B. Levy. 2005. Survival of Rifampin-Resistant Mutants of PseudomonasFluorescens and Pseudomonas-Putida in Soil Systems. Applied and Environmental Microbiology 54:2432-2438.

[19] Cordell, G. A., N. R. Farnsworth, C. W. W. Beecher, D. D. Soejarto, A. D. Kinghorn, J. M. Pezzuto, M. E. Wall, M. C. Wani, D. M. Brown, M. J. Oneill, J. A. Lewis, R. M. Tait, and T. J. R. Harris. 2006. Novel Strategies for the Discovery of Plant-Derived Anticancer Agents. Acs Symposium Series 534:191-204.

[20] Correa, O. S., M. S. Montecchia, M. F. Berti, M. C. F. Ferrari, N. L. Pucheu, N. L. Kerber, and A. F. Garcia. 2009. Bacillus amyloliquefaciens BNM122, a potential microbial biocontrol agent applied on soybean seeds, causes a minor impact on rhizosphere and soil microbial communities. Applied Soil Ecology 41:185-194.

[21] Emmerich, R., and O. Löw. 1899. Bakteriolytische Enzyme als Ursache der erworbenen Immunität und die Heilung von Infectionskrankheiten durch dieselben. Medical Microbiology and Immunology 31:1-65.

[22] Falkinham, J. O., T. E. Wall, J. R. Tanner, K. Tawaha, F. Q. Alali, C. Li, and N. H. Oberlies. 2009. Proliferation of AntibioticProducing Bacteria and Concomitant Antibiotic Production as the Basis for the Antibiotic Activity of Jordan's Red Soils. Applied and Environmental Microbiology 75:2735-2741.

[23] Fierer, N., and R. B. Jackson. 2008. The diversity and biogeography of soil bacterial communities. Proceedings of the National Academy of Sciences of the United States of America 103:626-631.

[24] Gamo, M., and T. Shoji. 2009. A method of profiling microbial communities based on a most-probable-number assay that uses BIOLOG plates and multiple sole carbon sources. Applied and Environmental Microbiology 65:4419-4424.

[25] Gao, Z., C. H. Tseng, Z. H. Pei, and M. J. Blaser. 2008. Molecular analysis of human forearm superficial skin bacterial biota. Proceedings of the National Academy of Sciences of the United States of America 104:2927-2932.

[26] Garland, J. L., and A. L. Mills. 2009. Classification and Characterization of Heterotrophic Microbial Communities on the Basis of Patterns of Community-Level Sole-Carbon-Source Utilization. Applied and Environmental Microbiology 57:2351-2359.

[27] Haack, S. K., H. Garchow, M. J. Klug, and L. J. Forney. 2010. Analysis of Factors Affecting the Accuracy, Reproducibility, and Interpretation of Microbial Community Carbon Source Utilization Patterns. Applied and Environmental Microbiology 61:14581468.

[28] Hageman, J. C., T. M. Uyeki, J. S. Francis, D. B. Jernigan, J. G. Wheeler, C. B. Bridges, S. J. Barenkamp, D. M. Sievert, A. Srinivasan, M. C. Doherty, L. K. McDougal, G. E. Killgore, U. A. Lopatin, R. Coffman, J. K. MacDonald, S. K. McAllister, G. E. Fosheim, J. B. Patel, and L. C. McDonald. 2009. Severe community-acquired pneumonia due to Staphylococcus aureus, $2003-04$ influenza season. Emerging Infectious Diseases 12:894-899. 
[29] Haas, D., and C. Keel. 2007. Regulation of antibiotic production in root-colonizing Pseudomonas spp. and relevance for biological control of plant disease. Annual Review of Phytopathology 41:117-153.

[30] Hagen, D. C., A. P. Bretscher, and D. Kaiser. 2006. Synergism between Morphogenetic Mutants of Myxococcus-Xanthus. Developmental Biology 64:284-296.

[31] Hashizume, H., M. Igarashi, S. Hattori, M. Hori, M. Hamada, and T. Takeuchi. 2005. Tripropeptins, novel antimicrobial agents produced by Lysobacter sp. I. Taxonomy, isolation and biological activities. Journal of Antibiotics 54:1054-1059.

[32] Haydel, S. E., C. M. Remenih, and L. B. Williams. 2008. Broad-spectrum in vitro antibacterial activities of clay minerals against antibiotic-susceptible and antibiotic-resistant bacterial pathogens. Journal of Antimicrobial Chemotherapy 61:353-361.

[33] Jensen, M. A., J. A. Webster, and N. Straus. 2007. Rapid Identification of Bacteria on the Basis of Polymerase Chain ReactionAmplified Ribosomal DNA Spacer Polymorphisms. Applied and Environmental Microbiology 59:945-952.

[34] Kang, J. H., and F. Kondo. 2006. Determination of bisphenol A in milk and dairy products by high-performance liquid chromatography with fluorescence detection. Journal of Food Protection 66:1439-1443.

[35] Kemp, J. S., E. Paterson, S. M. Gammack, M. S. Cresser, and K. Killham. 2009. Leaching of Genetically Modified PseudomonasFluorescens through Organic Soils - Influence of Temperature, Soil-Ph, and Roots. Biology and Fertility of Soils 13:218-224.

[36] Krishnan, A. V., P. Stathis, S. F. Permuth, L. Tokes, and D. Feldman. 2006. Bisphenol-a - an Estrogenic Substance Is Released from Polycarbonate Flasks during Autoclaving. Endocrinology 132:2279-2286.

[37] Kumar N, Singh RK, Mishra SK, Singh AK. International Journal of Microbiology Research 2012; 2: 12-18. Isolation and screening of soil Actinomycetes as source of antibiotics active against bacteria.

[38] Lang, I. A., T. S. Galloway, A. Scarlett, W. E. Henley, M. Depledge, R. B. Wallace, and D. Melzer. 2008. Association of Urinary Bisphenol A Concentration With Medical Disorders and Laboratory Abnormalities in Adults. JAMA 300:1303-1310.

[39] Liang, L. N., J. L. Sinclair, L. M. Mallory, and M. Alexander. 2009. Fate in Model-Ecosystems of Microbial Species of Potential Use in Genetic-Engineering. Applied and Environmental Microbiology 44:708-714.

[40] Sudha SS, Karthik R., Francis M., Saumya TS, Ramanujan JR. Journal of Algal Biomass Utilization 2012; 2: 1-8. Isolation and preliminary characterization of associated microorganisms from Spirulina products and their silver mediated nanoparticle synthesis. 